\title{
Present extent, features and regional distribution of Italian glaciers
}

Guglielmina Adele Diolaiuti ${ }^{1,11, a, *}$, Roberto Sergio Azzoni ${ }^{1, a}$, Carlo D'Agata $^{1,11, a}$, Davide Maragno ${ }^{1, a}$, Davide Fugazza $^{1,11, a}$, Marco Vagliasindi ${ }^{2,11, b}$, Giovanni Mortara ${ }^{11, b}$, Luigi Perotti ${ }^{3,11, b}$, Aldino Bondesan ${ }^{4,11, \mathrm{~b}}$, Alberto Carton ${ }^{4,11, \mathrm{~b}}$, Massimo Pecci ${ }^{10,11, \mathrm{~b}}$, Roberto Dinale ${ }^{5,11, \mathrm{~b}}$, Alberto Trenti ${ }^{6,11, \mathrm{~b}}$, Christian Casarotto ${ }^{7,11, \mathrm{~b}}$, Renato Roberto Colucci ${ }^{8,11, \mathrm{~b}}$, Anselmo Cagnati ${ }^{9,11, \mathrm{~b}}$, Andrea Crepaz ${ }^{9,11, \mathrm{~b}}$ and Claudio Smiraglia ${ }^{1,11, \mathrm{a}}$

${ }^{1}$ Dipartimento di Scienze e Politiche Ambientali, Università degli Studi di Milano, Milano, Italy

${ }^{2}$ Fondazione Montagna Sicura-Regione Autonoma Valle d'Aosta (FMS-RAVA), Courmayeur, Italy

${ }^{3}$ Dipartimento di Scienze della Terra, Università di Torino, Torino, Italy

${ }^{4}$ Dipartimento di Geoscienze, Università degli Studi di Padova, Padova, Italy

5 Autonome Provinz Bozen - Südtirol / Provincia autonoma di Bolzano - Alto Adige, Bolzano, Italy

${ }^{6}$ Provincia Autonoma di Trento, Trento, Italy

${ }^{7}$ Museo delle Scienze, Trento (MUSE), Trento, Italy

${ }^{8}$ ISMAR Trieste-CNR, Trieste, Italy

${ }^{9}$ Regione Veneto-ARPAV, Arabba, Italy

${ }^{10}$ Presidenza del Consiglio dei Ministri-Dipartimento affari regionali, autonomie e sport, Roma, Italy

${ }^{11}$ Comitato Glaciologico Italiano, CGI, Torino, Italy

Received: 6 May 2016 / Accepted: 5 August 2019

\begin{abstract}
Remote sensing investigations permit to map and describe at a regional scale and with a multitemporal approach mountain glaciers. In this work, we present some results from the New Italian Glacier Inventory which we developed by analyzing high-resolution color orthophotos acquired in the timeframe 2005-2011. In particular, in this paper we focused on each Italian Alpine Region, describing in detail glacier extent and features of each mountain group. Although Italian glaciologists were the first to produce glacier inventories (developing a glacier database as early as the beginning of the 20th century), during the last three decades only regional and local glacier lists have been developed. Therefore, a comprehensive study describing the actual whole Italian glaciation has been lacking. The New Italian Glacier Inventory describes 903 glaciers covering altogether an area of $368.10 \mathrm{~km}^{2} \pm 2 \%$. We found that about $84 \%$ of the total number of ice bodies is composed of glaciers smaller than $0.5 \mathrm{~km}^{2}$ covering only $21 \%$ of the total area, indicating that the Italian glacier resource is spread into several small ice bodies with only few larger glaciers. A comparison between the total glacier area of the new inventory and the glacier coverage value from the CGI Inventory (1959-1962) suggests a reduction of the glacier extent of about $30 \%$.
\end{abstract}

Keywords: remote sensing / glacier inventory / climate change / Alpine glaciers / Italian Alps

Résumé - Extension actuelle, caractéristiques et distribution régionale des glaciers italiens. L'utilisation de la télédétection permet de cartographier et décrire les glaciers de montagne à une échelle régionale et avec une approche multi-temporelle. Dans ce travail, nous présentons les principaux résultats du nouvel inventaire des glaciers italiens que nous avons développés en analysant les orthophotographies couleur haute résolution prises dans la période 2005-2011. En particulier, dans cet article, nous nous sommes concentrés sur chaque région, décrivant en détail la glaciation de chaque groupe de montagnes. Bien que les glaciologues italiens aient été les premiers à produire des inventaires des glaciers

\footnotetext{
*Correspondence: guglielmina.diolaiuti@unimi.it

a The authors who developed the New Italian Glacier Inventory, they

also analyzed the collected data and wrote the present paper.

$\mathrm{b}$ The authors who took part in the data validation process, in relation

to their areas of expertise.
} 
(en développant une base de données des glaciers dès le début du $20^{\mathrm{e}}$ siècle), au cours des trois dernières décennies seules des listes régionales et locales des glaciers ont été développées. Par conséquent, une étude approfondie décrivant l'ensemble de la glaciation italienne réelle a fait défaut. Le nouvel inventaire des glaciers italiens décrit 903 glaciers couvrant une surface totale de $368,10 \mathrm{~km}^{2} \pm 2 \%$. Nous avons observé que $84 \%$ environ du nombre total de glaciers est composée par de glaciers plus petits que $0,5 \mathrm{~km}^{2} \pm 2 \%$. Nous avons observé que $84 \%$ environ du nombre total de glaciers est composée par de glaciers plus petits que $0,5 \mathrm{~km}^{2}$, couvrant seulement $21 \%$ de la surface totale, en soulignant ainsi que la ressource glaciaire italienne est répartie en plusieurs petits corps de glace avec seulement quelques glaciers de plus grande dimension. Une comparaison entre la superficie totale des glaciers du nouvel inventaire et la valeur de couverture des glaciers de l'inventaire CGI (1959-1962) suggère une réduction de l'étendue des glaciers d'environ $30 \%$.

Mots clés : télédétection / inventaire des glaciers / changement climatique / glaciers alpine / Alpes italiennes

\section{Introduction}

Mountain glaciers represent precious landscape elements and valuable freshwater, energy and tourist resources. Most of all, glaciers are actual meaningful indicators of climate changes. Their strong area decrease offers a clear and unambiguous signal of the worldwide air temperature warming (Brunetti et al., 2000; Casty et al., 2005; Brohan et al., 2006). In particular, Italian glaciers over the last decades have been experiencing a shrinkage (Citterio et al., 2007; Diolaiuti et al., 2012a, b), which is comparable in magnitude and rates with the one observed on other Alpine sectors and on several glacierized mountain groups of the Planet (Paul et al., 2004b, 2007, 2011; Zemp et al., 2006, 2015; Beniston et al., 2018). A tool widely applied to evaluate glacier changes and variations in a changing climate is a glacier inventory. This latter is a glacier database where the main glacier features (i.e.: both quantitative and qualitative information) are listed, thus allowing the computation of glacier variations, if any, over a time window of several years or decades (depending on the frequency of remote sensing data acquisition, see Rau et al., 2005; Paul et al., 2007, 2011; Pfeffer et al., 2014). At the end of the Seventies (XX century) the International Commission for Snow and Ice (ICSI) organized a Symposium in Switzerland to discuss the guidelines for compiling a glacier inventory and they also listed the principal motivations supporting the development of a glacier database: 1) to improve the knowledge of water budget and hydrological cycle at a local, regional and global scale; 2) to provide technicians and scientists with valuable data to manage the freshwater resource (civil use, irrigation and hydropower) and to develop actual strategies of risk management; 3) to contribute to the analysis of environmental processes and natural phenomena linked to climate and its variations (Müller et al., 1977). Italy has a long and robust tradition in developing glacier inventories. Among the first glacier databases was the one realized by Carlo Porro in 1925 in the framework of the initiatives promoted and supported by the Italian Glaciological Committee (CGI from here); seven hundred and seventy four (774) glaciers are listed in this inventory (Porro, 1925; Porro and Labus, 1927). In this context, the most important work, also a novelty for the time, was the Italian Glacier Inventory; this latter was developed by the CGI in cooperation with the National Research Council (CNR) in the time-frame 1959-1962. This database was developed by analyzing already existing maps (scale 1:25 000, published by the Military Geographic Institute, the Italian public organization dependent on the Italian Army general staff who provided the official Italian cartography) and through field surveys. Eight hundred and thirty eight (838) glaciers were reported (considering both actual glaciers and glacierets), covering a total area of about $527 \mathrm{~km}^{2}$ (CGI-CNR, 1959, 1961a, b, 1962).

At the end of the Seventies (XX century), the CGI was part of the international team who developed the World Glacier Inventory (WGI from here), published in the Nineties as a synthesis only (Serandrei-Barbero and Zanon, 1993) and later with full details at the dedicated web page hosted by the World Glacier Monitoring Service web site (www.wgms.ch/, WGMS, 2012). In the WGI, the total area of the Italian glaciation was estimated to be about $608 \mathrm{~km}^{2}$, and a numeric increase of glaciers was reported (Belloni et al., 1985). The Italian data inserted in the WGI derived from aerial photo analysis and in some cases, the photos were affected by a non-negligible snow coverage. At the end of the Eighties, the CGI was designated by the Ministry of the Environment of the Italian Government to develop an updated glacier inventory. In the new database, the Italian glaciers were reported covering an area of about $480 \mathrm{~km}^{2}$ thus indicating an actual decrease with respect to both the CGI (1959-1962) inventory and the WGI (Ajassa et al., 1994, 1997). This was the last Italian inventory; no further national studies to develop a general glacier database were performed until the New Italian Glaciers Inventory (Smiraglia and Diolaiuti, 2015; Smiraglia et al., 2015) and the database produced by Salvatore et al. (2015) (Tab. 1).

Since then, only local (mainly regional) inventories were published (among the others: Zanon, 1990; SGL, 1992; Comitato Glaciologico Trentino, 1994; Citterio et al., 2007; Maragno et al., 2009; Knoll and Kerschner, 2009; Diolaiuti et al., 2011, 2012a, b; Bonardi et al., 2012; Secchieri, 2012; D'Agata et al., 2014) (for a more comprehensive list see Tab. 1).

Here we present the main results of the project named "The New Italian Glacier Inventory" which was developed to fill this scientific gap and which in quite a short time frame has produced an actual updated database describing the whole Italian glaciation (Smiraglia and Diolaiuti, 2015). Glacier data were extracted through remote sensing investigations, i.e.: by analyzing recent, high-resolution images. Here we describe the database structure, analyze the collected data and discuss the resulting picture of the actual Italian glacier resource.

\section{Data and methods}

\subsection{Sources of information, data accuracy and error assessment}

The fundamental source of data we used to develop the New Italian Glacier Inventory (i.e.: to detect glaciers, to mark their boundaries and to calculate their surface area) is 
G.A. Diolaiuti et al.: La Houille Blanche 2019, 5-6, 159-175

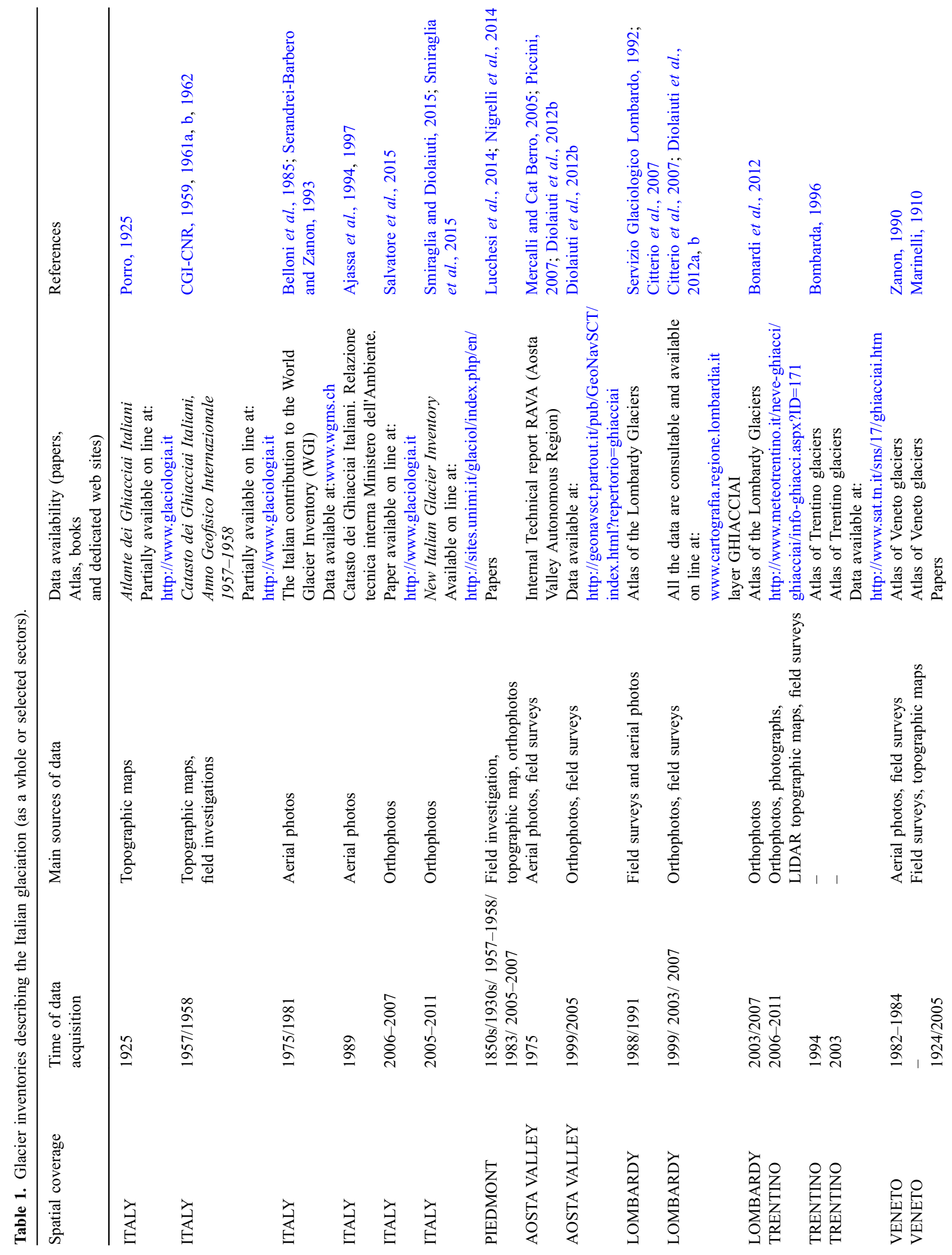


G.A. Diolaiuti et al.: La Houille Blanche 2019, 5-6, 159-175

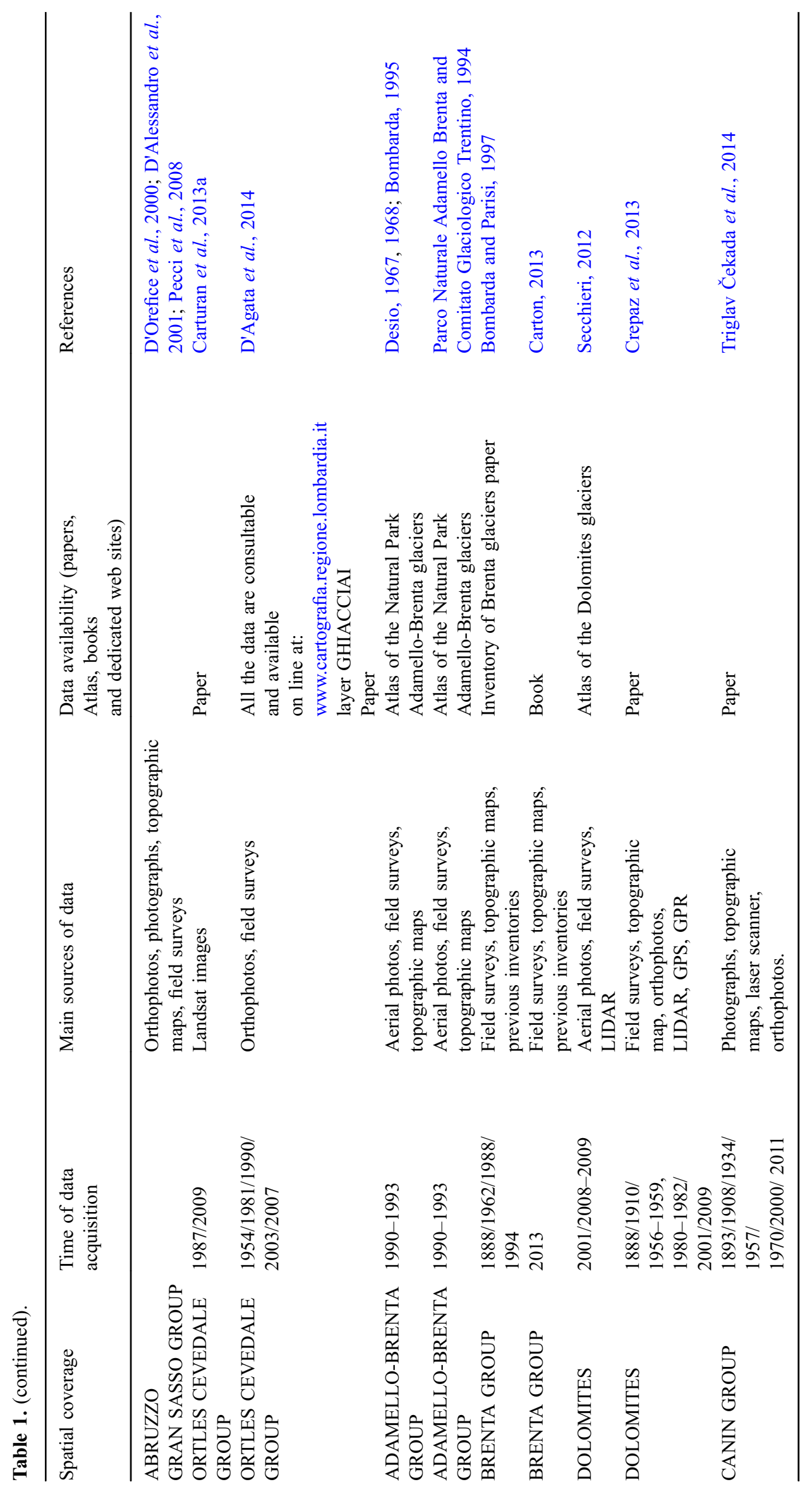




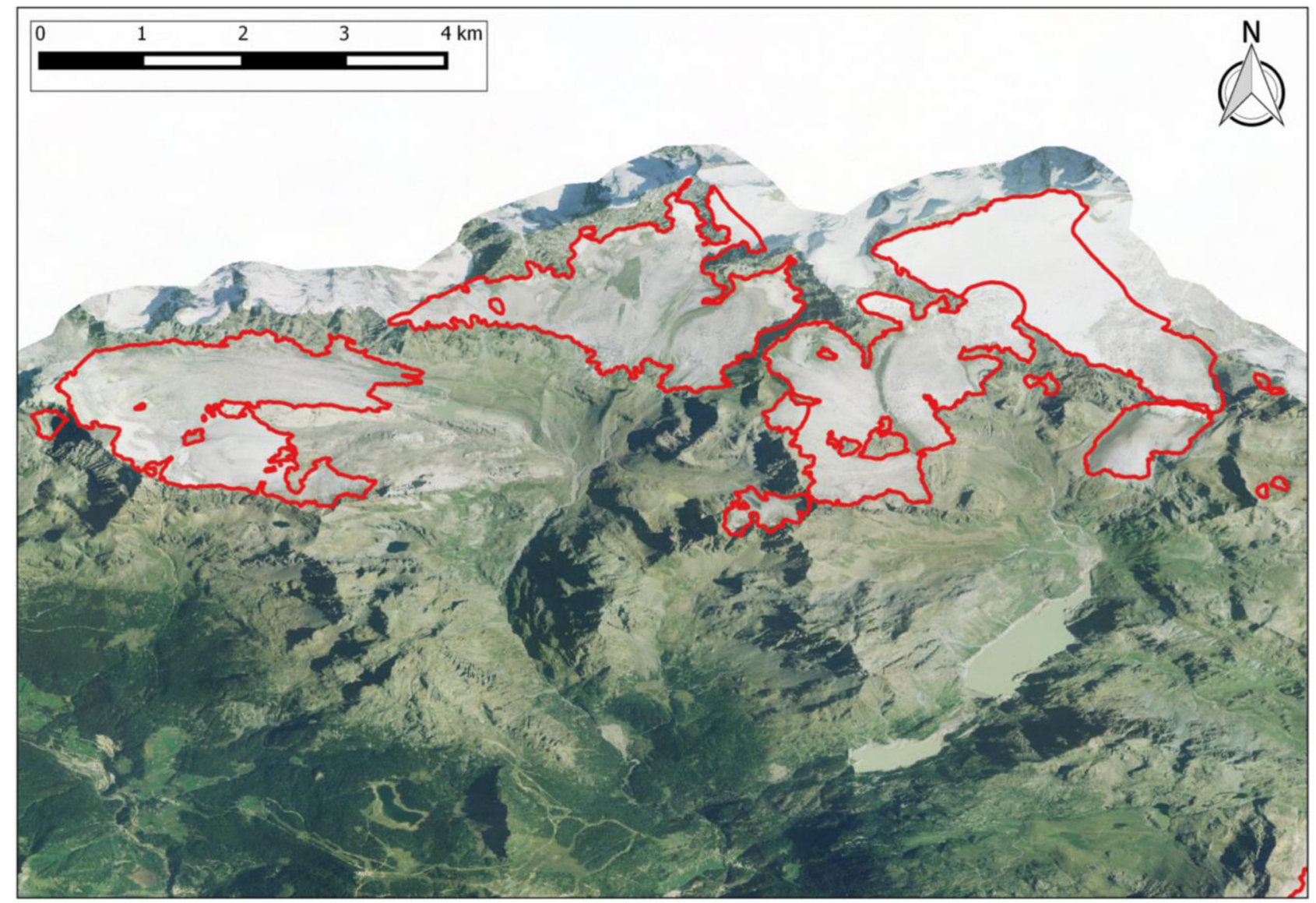

Fig. 1. An example of glacier boundaries mapped on the 2007 orthophotos (Flight Terraitaly IT2000 surveyed in 2007 by Blom CGR) located in the Bernina-Scalino Group.

represented by recent color orthophotos, kindly provided by Regional and local administrations. The orthophotos were obtained by means of high resolution aerial photography and feature low or absent cloud coverage; they were acquired at the end of the summer when glaciers show the minimum snow mantle and thus their margins are clearer and easier to detect. Aerial surveys were carried out in 2005 (Valle D'Aosta, RAVA Flight); 2007 (Lombardia, digital color orthophoto BLOMCGR S.p.A.-IIT2000/VERS.2007); 2008 (Provincia Autonoma di Bolzano Alto Adige, PAB Flight); 2009 (Veneto: LIDAR survey performed by Regione Veneto-ARPAV Centro Valanghe di Arabba); 2009-2011 (Regione Piemonte, ICE Flight); 2011 (Trentino, PAT Flight; Friuli Venezia-Giulia Unione Meteorologica FVG flight). The orthophotos feature a planimetric resolution specified by 1 pixel (pixel size $0.5 \times 0.5 \mathrm{~m}$ ). The planimetric accuracy stated by the manufacturers is $\pm 1 \mathrm{~m}$. The choice to use as main source of data orthophotos acquired in a quite wide time window (20052011) (although it must be underlined that for $92 \%$ of Italian glaciers the collected data refer to the more restricted period 2007-2011) is supported by the need of analyzing images affected by the smallest possible snow coverage, thus permitting to describe and map with high accuracy glacier boundaries. In a few cases, we also used satellite images to improve the glacier mapping (Valle d'Aosta, 2009 SPOT images) as well as field and literature data (Friuli-Venezia-
Giulia and Abruzzo). To detect and map glacier boundaries, the color orthophotos were imported as base layers in a GIS (Geographic Information System) environment (Fig. 1). Glacier areas were then calculated based on the detected boundaries. Values of surface area together with other crucial information (e.g.: glacier name, id code, coordinates, etc.) were inserted in a database, which constitutes the New Italian Glacier Inventory. The resulting glacier data were crosschecked against already existent regional or local inventories, recently published maps and cartography and performing dedicated field surveys. A team of experts selected by the Italian Glaciological Committee and/or from technical personnel of local administrations took part in the data validation process, in relation to their areas of expertise.

From the analysis of the orthophotos, we also derived information on glacier aspect and type (following the recommendations listed by Paul et al., 2009; Cogley et al., 2011; Pfeffer et al., 2014); these data were inserted in the New Italian Glacier inventory as well. Data describing glacier number, area coverage and type were also summarized at a general, regional and local (i.e.: mountain group) scale through diagrams and plots.

In order to allow comparisons among these new glacier data and the ones reported in previous regional and/or international inventories, we sorted the glaciers according to a size classification $\left(7\right.$ size classes: i.e.: $<0.10 \mathrm{~km}^{2} ; 0.10$ 
$0.5 \mathrm{~km}^{2} ; \quad 0.5-1 \mathrm{~km}^{2} ; \quad 1-2 \mathrm{~km}^{2} ; \quad 2-5 \mathrm{~km}^{2} ; \quad 5-10 \mathrm{~km}^{2}$ and $>10 \mathrm{~km}^{2}$ ). This classification was first introduced by Paul et al. (2004b) in their analysis of Swiss glaciers, and later applied to Italian glaciers by Citterio et al. (2007), Maragno et al. (2009), Diolaiuti et al. (2011, 2012a, b), D'Agata et al. (2014), Knoll and Kerschner (2009), Smiraglia et al. (2015) and Salvatore et al. (2015).

The potential error affecting data inserted in the new inventory was assessed following the approach introduced by Vögtle and Schilling (1999) and widely applied in the recent past, e.g. to evaluate the surface area error of Lombardy glaciers (Citterio et al., 2007; Diolaiuti et al., 2012a) and of Aosta Valley glaciers (Diolaiuti et al., 2012b). This method is based on the calculation of the surface area buffer for each mapped glacier. The buffer extent depends on the glacier boundary, the pixel size and the uncertainty of the applied mapping (this latter due to the manual operator and evaluated for each glacier in relation to the experience of the operator and to his/her knowledge of the surveyed glacier area). We determined the final precision of the whole glacier coverage by taking the root of the squared sum of all the buffer areas. Thanks to the high quality and resolution of the orthophotos and to the accurate manual delineation, the resulting glacier areas featured an error lower than $\pm 2 \%$ of the actual value. Few exceptions occur in the case of supraglacial debris presence (i.e.: debris covered glaciers, both sensu strictu and sensu latu, see Kirkbride, 2011 and Smiraglia and Diolaiuti, 2011). These conditions have become even more frequent in the last years and complicate the detection and mapping of glacier outlines; in particular, mapping of the glacier snout is difficult since at the lower elevation debris coverage can reach higher depth. Under such conditions, underestimation of the glacier area can reach $10 \%$ of the actual value. To reduce the error, whenever debris occurs at the glacier surface, we also considered glacier morphological features; in fact, these latter might indicate the presence of buried ice thus improving the correct mapping of glacier limits. We took into account the occurrence of: ice cliffs and ice pinnacles, bédières and epiglacial streams, supraglacial lakes and water ponds, glacier moulins and surface roughness, dark areas due to higher water content or areas showing clear changes of elevation, meltwater streams originating from heavily debris-covered areas (Paul et al., 2004a, 2009). In some selected cases, whenever supraglacial debris cover was abundant, thus partially or totally covering the ablation area (i.e.: Miage, Lys, Belvedere and Solda glaciers), we also performed ad hoc GPS (Global Positioning System) field surveys to map the actual glacier boundaries.

Last but not least, shadow occurrence can cause an increase in the error affecting the areas. Therefore, in our work we decided to avoid shadow areas, which in the orthophotos we analyzed represent a small part of the total (less of $1 \%$ of the whole glacierized area).

In this study, the cumulative area of all Italian glaciers is slightly different $(-0.49 \%)$ from the number reported by Smiraglia et al. (2015), and so are regional cumulative areas in a few cases and data concerning individual glaciers. This is due to the correction of a small number of inaccuracies contained in the first edition of the Inventory. See the final version of the data (revision 2016) at http://sites.unimi.it/ glaciol/index.php/en/.

\subsection{Glacier Inventory parameters}

We followed the World Glacier Monitoring Service (WGMS) "guidelines for the compilation of glacier inventory data from digital sources" version 1.0 (Paul et al., 2009) to derive the parameters for individual glaciers inserted in the New Italian Glacier Inventory. We inserted the most important parameters to describe the Italian glaciation from both a numerical and descriptive point of view (Kargel et al., 2014; Pfeffer et al., 2014). The main criteria supporting the choice of these parameters were: 1) to univocally identify each glacier (through a name and an ID code, this latter was reported as both CGI code and WGI code); 2) to indicate the correct location of each glacier (through the mean coordinates and reporting mountain group and catchments nesting the analyzed glacier); 3) to describe the actual type and features of each glacier (by reporting glacier type, area and main aspect clearly stating the survey year); 4) to give the opportunity for further implementation of this new database (through the field "Note" where any other data can be reported). In a special Annex, other morphometric parameters (among others, glacier minimum, mean and maximum elevation, length, slope) have been collected to improve the database. In this presentation, we chose to limit our analysis to the area parameters only. In fact, glacier area values are surely the most important and crucial data (Pfeffer et al., 2014) since they support further analysis, also at a global scale, to model glacier volume (thus providing a raw estimation of the glacier-derived freshwater resource) and, whenever coupled with Digital Elevation Models (DEMs), to assess glacier volume changes and to estimate glacier mass balance.

\section{Results}

\subsection{The glaciers of Italy}

About $1 / 5$ th of all Alpine glaciers is located on the Italian side of the Alps. A total glacierized area of $368.10 \mathrm{~km}^{2} \pm 1 \%$ was found (Fig. 2), a non-negligible value if compared to the Alps as a whole $\left(2050 \mathrm{~km}^{2}\right.$, Paul et al., 2011). The total number of Italian glaciers is 903 (including two small ice bodies making up the Calderone Glacier on the Apennines), a large value if compared to the Alpine census as a whole (3370 glaciers, Paul et al., 2011) with an ample distribution, from the Maritime to the Julian Alps. The glacier size and type cover a wide range as well: from the widest Italian glacier, the Adamello plateau glacier, to Lys and Forni, large valley glaciers which feature several accumulation basins (and are therefore classified as "confluent valley glaciers"), to the small mountain glaciers and glacierets.

Concerning the glacier census, the highest number of glaciers was found in Lombardy (230), then in South Tyrol (212), in Aosta Valley (192), in Trentino (Autonomous Province of Trento) (115) and in Piedmont (107). A very small number of glaciers is located in Veneto, in Friuli-Venezia Giulia and in Abruzzo (38; 7 and 2 respectively) (Tab. 2).

The Italian glaciation is formed by several small and smaller ice bodies: the average area of all Italian glaciers was found equal to $0.41 \mathrm{~km}^{2}$, on a regional level the mean values ranged from $0.70 \mathrm{~km}^{2}$ (Aosta Valley) to $0.09 \mathrm{~km}^{2}$ (Veneto). 


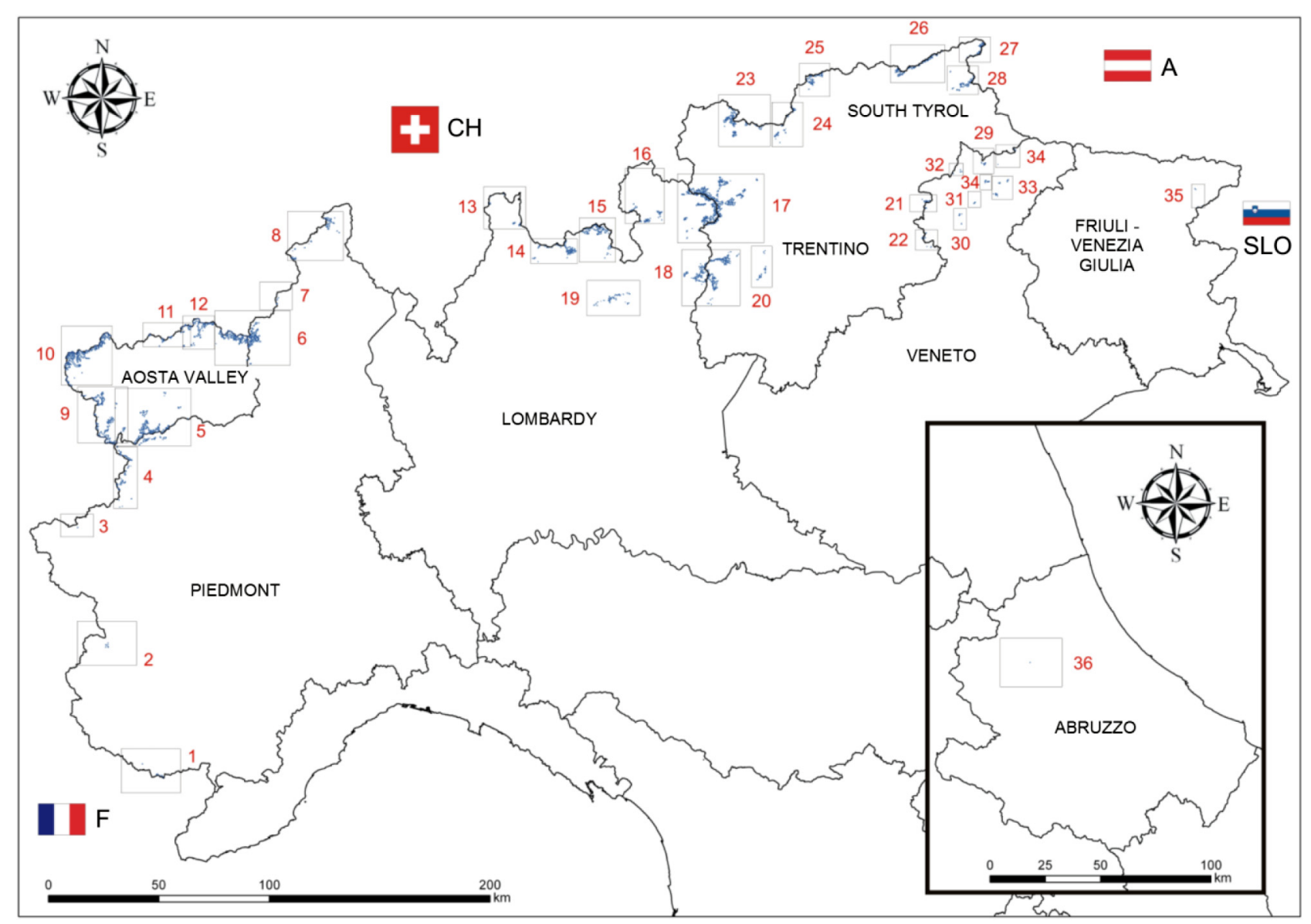

Fig. 2. Distribution map of Italian glaciers. The numbered black boxes correspond to the Italian mountain groups where the glaciers are located. The toponym of each mountain group is reported in the table of the corresponding Region or Province.

Table 2. Surface area and number of the Italian glaciers sorted according to the Region where they are located.

\begin{tabular}{lcccc}
\hline Region & $\begin{array}{c}\text { Number } \\
\text { of glaciers }\end{array}$ & $\begin{array}{c}\text { Cumulative area } \\
\text { value }\left(\mathrm{km}^{2}\right)\end{array}$ & $\begin{array}{c}\text { Region contribution } \\
\text { to the whole } \\
\text { Italian coverage (\%) }\end{array}$ & $\begin{array}{c}\text { Region contribution to } \\
\text { the total number of } \\
\text { Italian glacier (\%) }\end{array}$ \\
\hline PIEDMONT & 107 & 28.55 & 7.76 & 11.85 \\
AOSTA VALLEY & 192 & 132.90 & 36.10 & 21.26 \\
LOMBARDY & 230 & 87.67 & 23.82 & 25.47 \\
TRENTINO & 115 & 30.96 & 8.41 & 12.74 \\
SOUTH TYROL & 212 & 84.58 & 22.98 & 23.48 \\
VENETO & 38 & 3.21 & 0.87 & 0.05 \\
FRIULI-VENEZIA & 7 & 0.19 & 0.01 & 0.77 \\
GIULIA & 2 & 0.04 & 100 & 0.22 \\
ABRUZZO & 903 & 368.10 & & 100 \\
ITALY & & &
\end{tabular}

Analyzing the 903 inventoried Italian glaciers, we found that the largest part of their area shows a prevalent North aspect (NW, N and NE) (61\% of the glacierized area and $54 \%$ of the glaciers feature a North, North-West and North East aspect) (Fig. 3A).

The size distribution of the Italian glaciation (Tab. 3) was found in agreement with other sectors of the Alps and other glacierized mountain chains of the Planet (Paul et al., 2004b;
Racoviteanu et al., 2008; Diolaiuti et al., 2012a, b), with a large number of small ice bodies $\left(i . e .:<1 \mathrm{~km}^{2}\right)$ and only few large glaciers (i.e.: $>10 \mathrm{~km}^{2}$ ). According to this size classification, $84 \%$ of the total glaciers are smaller than $0.5 \mathrm{~km}^{2}$ covering only the $21 \%$ of the total area. On the other hand, glaciers wider than $1 \mathrm{~km}^{2}$ (i.e. $9.4 \%$ of the total number) cover $67.8 \%$ of the total area. The Adamello Glacier $\left(16.30 \mathrm{~km}^{2}\right)$ in both Lombardy and Trentino, the Forni Glacier 


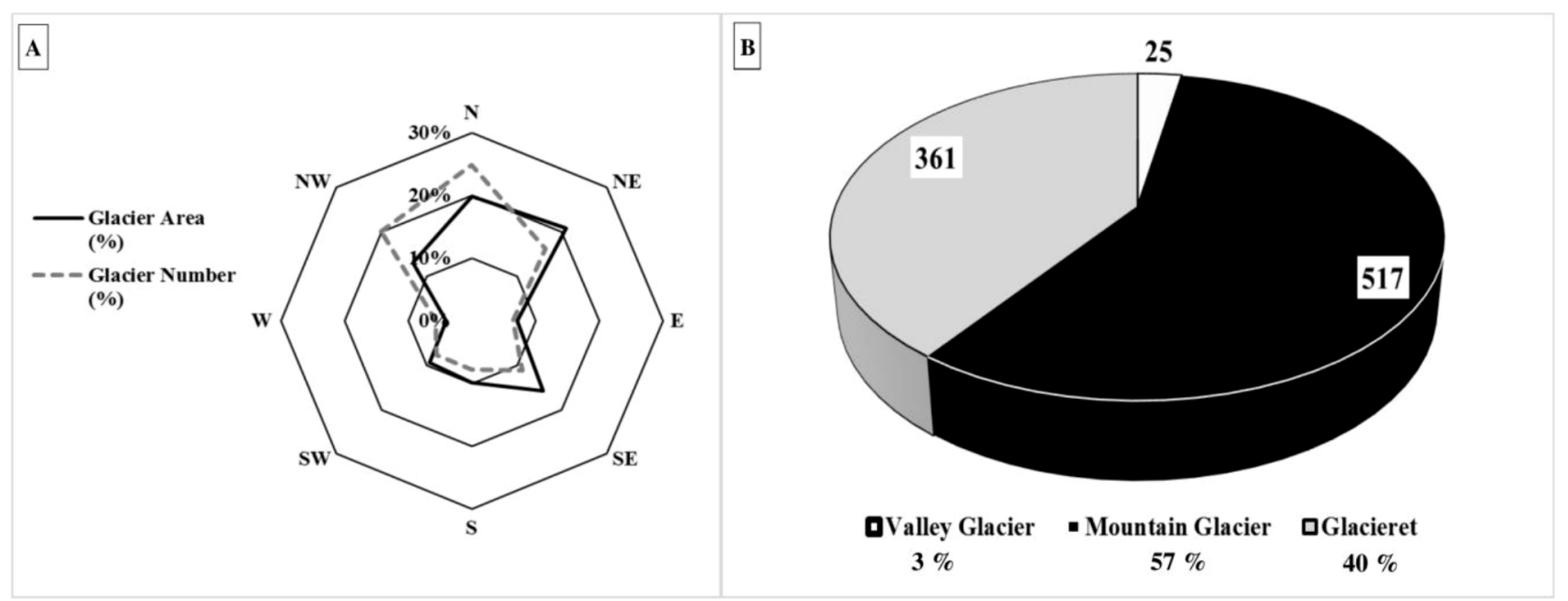

Fig. 3. A. Aspect frequency distribution of Italian glaciers. The percent of glacier area (black line) and glacier number (black dotted line) in $45^{\circ}$ aspect bins are reported. B. Type frequency of the Italian glaciers. The legend reports the percentage value (\%) with respect to the total Italian glaciers, whereas the labels on the graph indicate the number of glaciers belonging to each type class.

Table 3. Area distribution of the Italian glaciers sorted according to size classes.

\begin{tabular}{lcccc}
\hline Size class & $\begin{array}{c}\text { Number } \\
\text { of glaciers }\end{array}$ & $\begin{array}{c}\text { Cumulative area } \\
\text { value }\left(\mathrm{km}^{2}\right)\end{array}$ & $\begin{array}{c}\text { Size class } \\
\text { contribution to the } \\
\text { whole Italian area (\%) }\end{array}$ & $\begin{array}{c}\text { Size class contribution } \\
\text { to the total number } \\
\text { of Italian glaciers (\%) }\end{array}$ \\
\hline$<0.1 \mathrm{~km}^{2}$ & 497 & 19.76 & 5.4 & 55.0 \\
$0.1-0.5 \mathrm{~km}^{2}$ & 263 & 56.58 & 15.4 & 29.1 \\
$0.5-1 \mathrm{~km}^{2}$ & 58 & 41.85 & 11.3 & 6.4 \\
$1-2 \mathrm{~km}^{2}$ & 42 & 56.08 & 15.2 & 4.7 \\
$2-5 \mathrm{~km}^{2}$ & 32 & 102.91 & 28.0 & 3.5 \\
$5-10 \mathrm{~km}^{2}$ & 8 & 53.72 & 14.6 & 0.9 \\
$>10 \mathrm{~km}^{2}$ & 3 & 37.47 & 10.2 & 0.3 \\
Total & 903 & 368.10 & 100 & 100 \\
\hline
\end{tabular}

$\left(11.36 \mathrm{~km}^{2}\right)$ in Lombardy and the Miage Glacier $\left(10.47 \mathrm{~km}^{2}\right)$ in Aosta Valley are the only three glaciers that belong to the biggest size class $\left(>10 \mathrm{~km}^{2}\right)$ and cover about $10.3 \%$ of the Italian glacierized area. These findings are in according with the type classification: only 25 glaciers $(2.8 \%$ of the total census) were labeled as "valley glacier" and the largest part of the sample was labeled as "mountain glacier" (i.e. 517 corresponding to $57.3 \%$ ) and "glacieret" (i.e. 361 ice bodies corresponding to $40 \%$ ). This further indicates a glaciation spread into several small ice bodies with only few larger glaciers (Fig. 3B).

\subsection{The glacierized regions of Italy}

In detail, considering the different Italian Regions (see Tab. 4, Figs. 4-6 for further details), one-hundred and seven (107) glaciers are found in Piedmont covering a total area of $28.55 \mathrm{~km}^{2}$. Aosta Valley host 192 glaciers (Tab. 5) covering a total area of $132.90 \mathrm{~km}^{2}$, thus making it the most glacierized area of Italy. The list of Aosta Valley glaciers in the New Italian Glacier Inventory is slightly different from the one reported in the Aosta Valley Autonomous Region (RAVA) Glacier database (developed by the same authors of the New Italian Glacier Inventory in cooperation with RAVA through the "Cabina di Regia dei Ghiacciai Valdostani"), based on 2005 orthophotos and freely available at the official web GIS of the Aosta Valley Region (http://geoportale.partout.it/cartografia/ info_geoscientifiche_i.aspx). In fact, in the New Italian Glacier Inventory we selected 192 glaciers from the whole Aosta Valley sample by applying an area threshold (i.e.: $0.01 \mathrm{~km}^{2}$ ). This selection did not affect our analysis since it led only a slight underestimation (less than $0.5 \mathrm{~km}^{2}$ ).

Lombardy is the top region considering the number of glaciers (Tab. 6; 230 ice bodies covering $87.67 \mathrm{~km}^{2}$ ) This latter is smaller than the one reported in the Lombardy Glacier Regional database (which listed 308 ice bodies) developed by the same authors of the New Glacier Inventory, based on 2007 orthophotos and freely available at the official web GIS of the Lombardy Region (www.cartografia.regione.lombardia.it). In the New Italian Glacier Inventory, we selected 230 glaciers from the whole Lombardy sample by applying an area threshold (i.e.: $0.01 \mathrm{~km}^{2}$ ). This selection did not affect our 
Table 4. Surface area and number of the Piedmont glaciers sorted according to the mountain groups where they are located. The number associated to each mountain group is related to the black boxes of the Figure 2.

\begin{tabular}{lcccc}
\hline Mountain group & $\begin{array}{c}\text { Number } \\
\text { of glaciers }\end{array}$ & $\begin{array}{c}\text { Cumulative area } \\
\text { value }\left(\mathrm{km}^{2}\right)\end{array}$ & $\begin{array}{c}\text { Mountain group } \\
\text { contribution to the total } \\
\text { region area (\%) }\end{array}$ & $\begin{array}{c}\text { Mountain Group contribution } \\
\text { to the total number of } \\
\text { Piedmont glaciers (\%) }\end{array}$ \\
\hline 1 - ALPI MARITTIME & 6 & 0.41 & 1.4 & 5.6 \\
2 - MONVISO & 7 & 0.26 & 0.9 & 6.5 \\
3 - MONCENISIO & 1 & 0.07 & 0.2 & 0.9 \\
4 - ALPI GRAIE MERIDIONALI & 26 & 5.45 & 19.1 & 24.3 \\
5 - GRAN PARADISO & 18 & 3.40 & 11.9 & 16.8 \\
6 - MONTE ROSA & 22 & 12.85 & 45.0 & 20.6 \\
7 - MISCHABEL & 3 & 0.28 & 1.0 & 2.8 \\
8 - LEONE-GOTTARDO & 24 & 5.83 & 20.4 & 22.4 \\
TOTAL & 107 & 28.55 & 100 & 100 \\
\hline
\end{tabular}

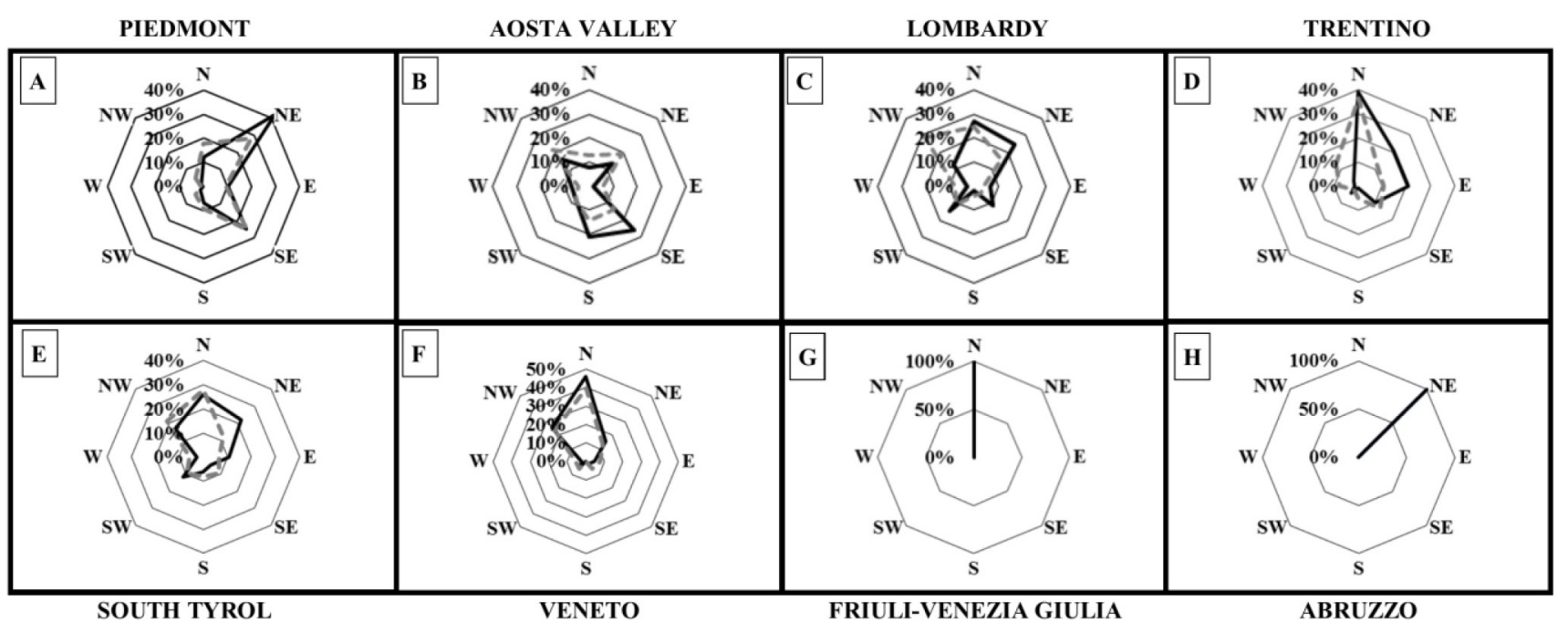

Fig. 4. Aspect frequency distribution of Italian glaciers. Each administrative Region is considered. Numbers represent the percent of glacier area in $45^{\circ}$ aspect bins.

analysis since it led only a slight underestimation (less than $1 \mathrm{~km}^{2}$ ), thus not impacting on the derived results.

Some Lombardy glaciers intersect the Region boundary (i.e. Adamello and Zebrù Ovest). Therefore, in developing the New Italian Glacier Inventory, we chose to include these ice bodies in the Lombardy list, but when computing the total regional coverage we did not consider the glacier areas outside the boundary. This method has been applied in all of other similar situations. One hundred and fifteen ice bodies are located in Trentino covering $30.96 \mathrm{~km}^{2}$ (including a portion of Adamello glacier). Moreover, in order to better clarify the glacierized area of the Trento Province, in 2002 a Memorandum of Understanding between the Autonomous Province of Trento and the Veneto Region stated that the Autonomous Province of Trento has competence within all the territory of the Marmolada Glacier. Accordingly, the values we listed in Table 7 refer to the new provincial boundaries, thus affecting evaluation of glacier area changes. In fact, in the Autonomous Province of Trento, glacier area decreased to the ongoing climate change but on the other hand the change of administrative borders resulted in a mitigation of the actual glacier area losses experienced by the Trentino territory (which has gained a glacier sector previously listed in the Veneto).

South Tyrol hosts 212 glaciers covering a total area of $84.58 \mathrm{~km}^{2}$ (including a portion of Zebrù Ovest; Tab. 8): this values are lower than the ones reported by Knoll and Kerschner (2009) who listed 302 ice bodies. In the New Italian Glacier Inventory, we selected 212 glaciers from the whole South Tyrol sample by applying an area threshold (i.e.: $0.01 \mathrm{~km}^{2}$ ). Moreover, the work by Knoll and Kerschner (2009) was based on glacier outlines delimited on 2006 imagery, whereas our record was based on more recent data, i.e.: 2008 colour orthophotos, thus further explaining the small difference between the two glacier lists. Thirty-eight ice bodies are located in Veneto (Tab. 9) covering an area of $3.21 \mathrm{~km}^{2}$ altogether. In this region, the area variations will be affected not only by glacier shrinkage, but also by the changes of administrative borders, which result in an increase of the glacier area losses experienced by Veneto. 
PIEDMONT

AOSTA VALLEY
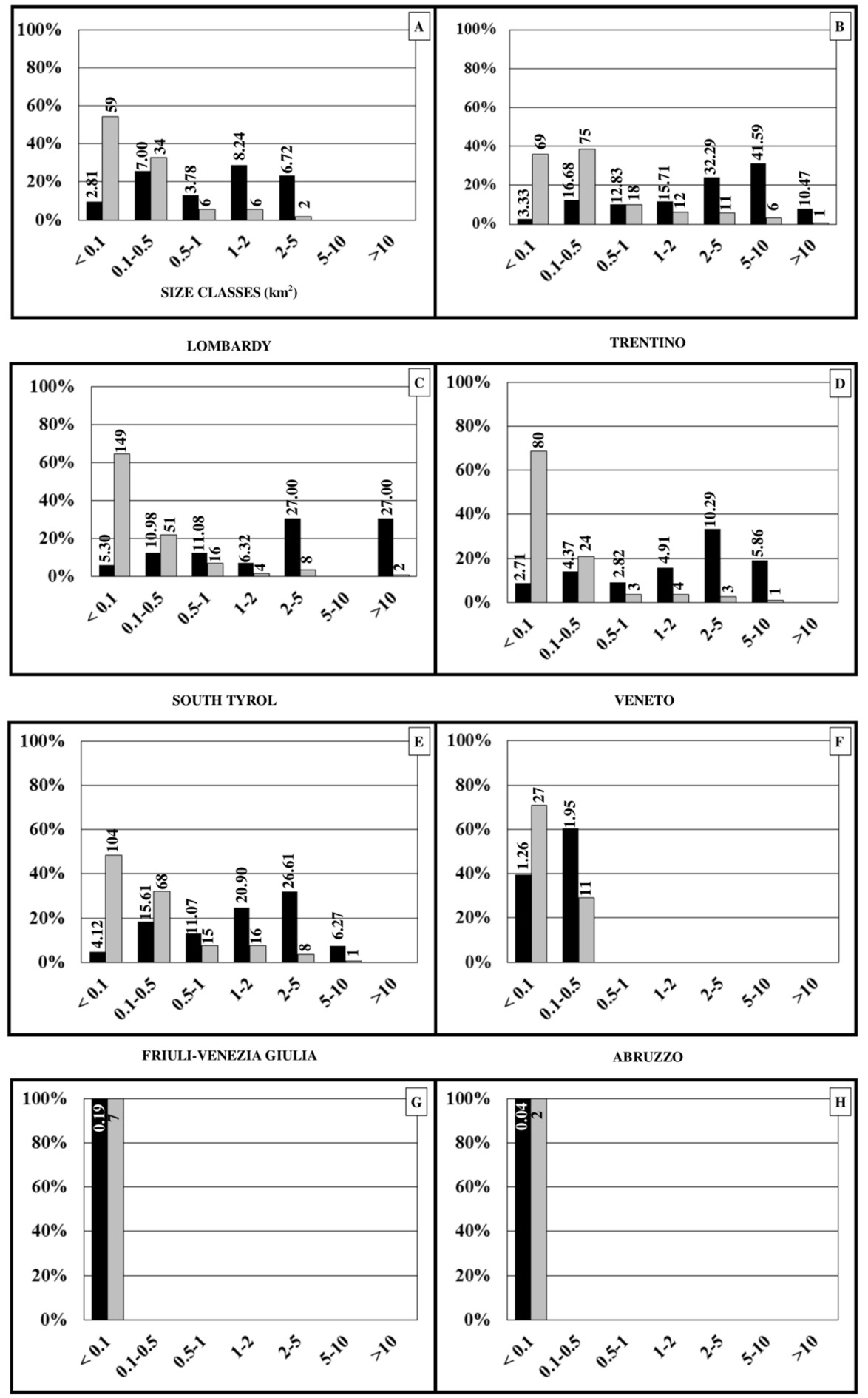

Fig. 5. Area and number frequency distribution of the Italian glaciers. Each administrative Region is considered. The black bars represent the area frequency distribution reported as percentage values (\%) with respect to the total coverage. The gray bars indicate the number frequency distribution of the Italian glaciers (percentage values (\%) with respect to the total glacier number). Numbers and area were sorted according to 7 size classes. The labels show the surface and the number of glaciers in each size class.

Only seven glaciers (Tab. 10), covering a total area of $0.19 \mathrm{~km}^{2}$ (mean glacier value $0.03 \mathrm{~km}^{2}$ ), are found in FriuliVenezia Giulia. All the Friuli-Venezia Giulia glaciers are located in the Julian Alps (Montasio-Canin group, Tab. 10) and the cirque valleys nesting these small ice bodies feature high and steep slopes. The Friuli - Venezia Giulia glaciers are still present and active due to their North preferred aspect (Fig. 4G, which reduces the incoming solar energy fluxes thus mitigating melting 


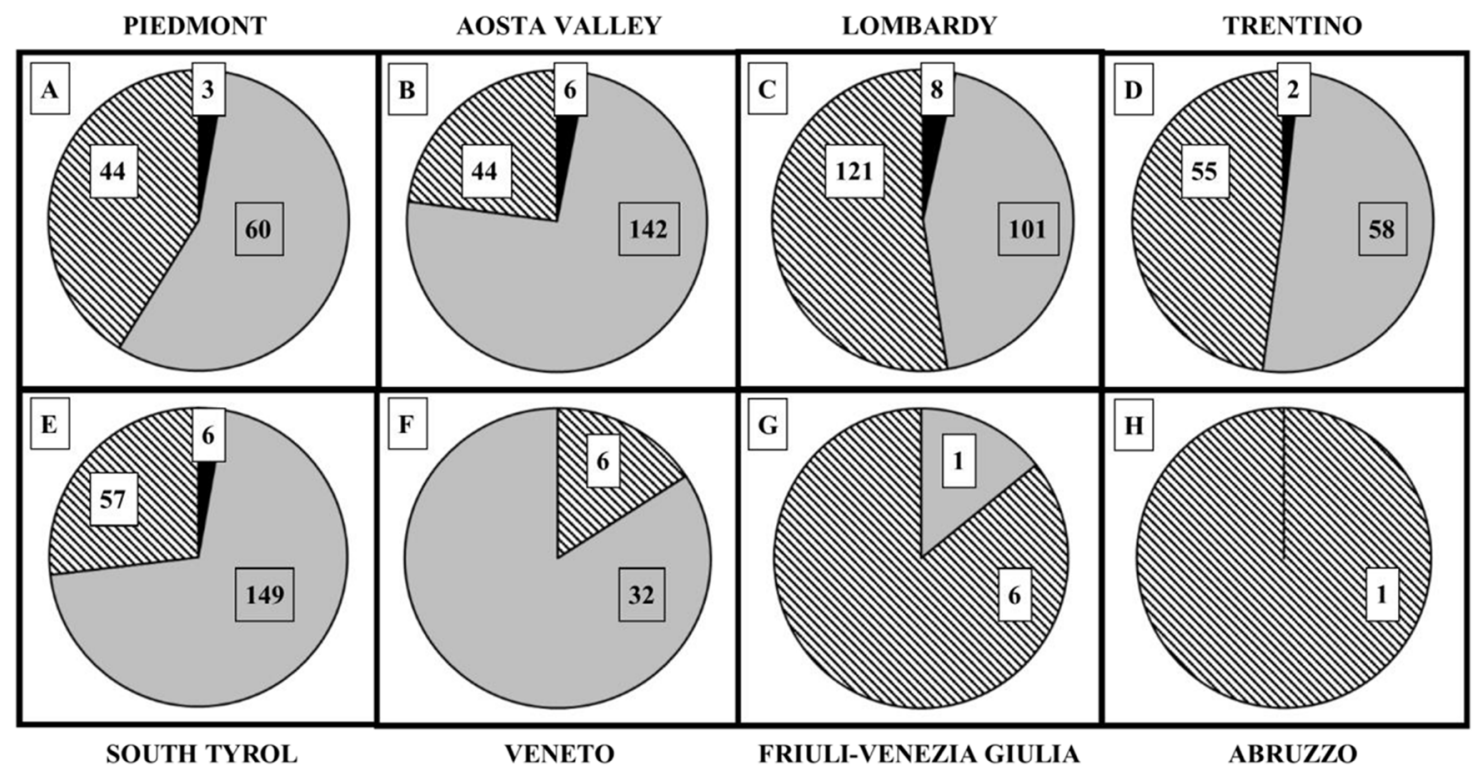

Fig. 6. Type frequency of the Italian glaciers. Each administrative Region is considered. The grey area was used to mark "mountain glacier" type, the banded coverage indicates "glacieret" and the black color is used to indicate "valley glacier" type. The labels on the graph are the number of glaciers belonging to each type class.

Table 5. Surface area and number of the Aosta Valley glaciers sorted according to the mountain groups where they are located.

\begin{tabular}{lcccc}
\hline Mountain group & $\begin{array}{c}\text { Number of } \\
\text { glaciers }\end{array}$ & $\begin{array}{c}\text { Cumulative area } \\
\text { value }\left(\mathrm{km}^{2}\right)\end{array}$ & $\begin{array}{c}\text { Mountain group contribution } \\
\text { to the total region area (\%) }\end{array}$ & $\begin{array}{c}\text { Mountain group contribution } \\
\text { to the total number of Aosta } \\
\text { Valley glaciers (\%) }\end{array}$ \\
\hline 5 - GRAN PARADISO & 40 & 23.36 & 17.6 & 20.8 \\
9 - GRANDE SASSIERE-RUTOR & 68 & 28.49 & 21.4 & 35.4 \\
10 - MONTE BIANCO & 31 & 36.85 & 27.7 & 16.1 \\
11 - GRAND COMBIN & 17 & 3.21 & 2.4 & 8.9 \\
12 - CERVINO & 24 & 15.88 & 11.9 & 12.5 \\
6 - MONTE ROSA & 12 & 25.11 & 18.9 & 6.3 \\
TOTAL & 192 & 132.90 & 100 & 100 \\
\hline
\end{tabular}

rates), to both intensity and frequency of snowfall, and to the actual snow feeding mainly provided by both frequent avalanche events and wind deposition phenomena (Carturan et al., 2013b; Triglav Čekada et al., 2014; Colucci and Guglielmin, 2015; Colucci et al., 2015). It must be underlined that Julian Alps feature heavier and more frequent precipitation with respect to other Alpine sectors (Isotta et al., 2014). In fact, the mean annual precipitation (MAP) value reaches up to $3300 \mathrm{~mm}$ on the Canin massif, representing one of the highest data for the Alps and Europe (Norbiato et al., 2007; Colucci and Guglielmin, 2015).

Only two small glacierets, deriving from fragmentation of the Calderone Glacier (Tab. 11), which occurred in 2000, are found in the Abruzzo (Fiucci et al., 1997; Pecci et al., 2001).

\section{Discussion}

The Alpine glaciation represents a very small portion of the European one (see Fig. 7 for further details). In particular, the total area of European glaciers is $87247 \mathrm{~km}^{2}$ (data from WGMS and NSIDC, 2012), but $82 \%$ of the whole glacierized surface is located in the European Artic archipelagoes, mainly in the Svalbard (Nuth et al., 2013). The European glaciation sensu strictu consists in $15950 \mathrm{~km}^{2}$, largely due to the Icelandic glaciation. The remaining part of European glaciers are located in the Scandinavian Peninsula $\left(3005 \mathrm{~km}^{2}\right.$ and in the Alps $\left(2060 \mathrm{~km}^{2}\right)$ (data from WGMS and NSIDC, 2012). Considering the European glaciation sensu strictu, many authors have examined glaciers on a national scale: data from Renè (2001), Hughes (2007, 2009), Lambrecht and Kuhn (2007), Gadek and Grabiec (2008), González Trueba et al. (2008), Gachev et al. (2009), Andreassen et al. (2012), Hagg et al. (2012), Fisher et al. (2014), Gardent et al. (2014), Triglav Čekada et al. (2014) are reported in Figure 7. Focusing on Alpine glaciation, Paul et al. developed in the 2011 the European Alps glacier inventory using 2003 Landsat scenes and found 3700 ice bodies covering $2050 \mathrm{~km}^{2}$ (2080-2100 km² including several small glaciers).

Comparing the Alpine and European data with the present Italian glaciation, it results that in Italy glaciers cover $368.10 \mathrm{~km}^{2}$ equal to the $18 \%$ of the whole Alps glacierized area, but only $2 \%$ of the European glaciation sensu strictu.

A first comparison between the total glacier area computed for the time window 2005-2011 and the glacier coverage value 
G.A. Diolaiuti et al.: La Houille Blanche 2019, 5-6, 159-175

Table 6. Surface area and number of the Lombardy glaciers sorted according to the mountain groups where they are located.

\begin{tabular}{lcccc}
\hline Mountain group & $\begin{array}{c}\text { Number of } \\
\text { glaciers }\end{array}$ & $\begin{array}{c}\text { Cumulative area } \\
\text { value }\left(\mathrm{km}^{2}\right)\end{array}$ & $\begin{array}{c}\text { Mountain group } \\
\text { contribution to the } \\
\text { region area (\%) }\end{array}$ & $\begin{array}{c}\text { Mountain group contribution } \\
\text { to the total number of Lombardy } \\
\text { glaciers (\%) }\end{array}$ \\
\hline 13 - TAMBO'-STELLA & 12 & 1.83 & 2.1 & 5.2 \\
14 - CASTELLO-DISGRAZIA & 44 & 8.19 & 9.3 & 19.1 \\
15 - BERNINA-SCALINO & 21 & 21.27 & 24.3 & 9.1 \\
16 - LIVIGNO-PIAZZI & 26 & 4.23 & 4.8 & 11.3 \\
17 - ORTLES-CEVEDALE & 51 & 28.58 & 32.6 & 22.2 \\
18 - ADAMELLO & 34 & 21.62 & 24.7 & 14.8 \\
19 - OROBIE & 42 & 1.95 & 2.2 & 18.3 \\
TOTAL & 230 & 87.67 & 100 & 100 \\
\hline
\end{tabular}

Table 7. Surface area and number of glaciers in Trentino sorted according to the mountain groups where they are located.

\begin{tabular}{lcccc}
\hline Mountain group & $\begin{array}{c}\text { Number of } \\
\text { glaciers }\end{array}$ & $\begin{array}{c}\text { Cumulative area } \\
\text { value }\left(\mathrm{km}^{2}\right)\end{array}$ & $\begin{array}{c}\text { Mountain group } \\
\text { contribution to the } \\
\text { province area (\%) }\end{array}$ & $\begin{array}{c}\text { Mountain group contribution } \\
\text { to the tal number of glaciers in } \\
\text { Trentino (\%) }\end{array}$ \\
\hline 17 - ORTLES - CEVEDALE & 24 & 9.22 & 29.8 & 20.9 \\
18 - ADAMELLO-PRESANELLA & 58 & 19.05 & 61.5 & 50.4 \\
20 - BRENTA & 20 & 0.86 & 2.8 & 17.4 \\
$21-$ MARMOLADA & 7 & 1.54 & 5.0 & 6.1 \\
$22-$ PALE DI SAN MARTINO & 6 & 0.29 & 0.9 & 5.2 \\
TOTAL & 115 & 30.96 & 100 & 100 \\
\hline
\end{tabular}

Table 8. Surface area and number of glacier in South Tyrol sorted according to the mountain groups where they are located.

\begin{tabular}{|c|c|c|c|c|}
\hline Mountain group & $\begin{array}{l}\text { Number of } \\
\text { glaciers }\end{array}$ & $\begin{array}{l}\text { Cumulative area } \\
\text { value }\left(\mathrm{km}^{2}\right)\end{array}$ & $\begin{array}{l}\text { Mountain group } \\
\text { contribution to the total } \\
\text { province area }(\%)\end{array}$ & $\begin{array}{l}\text { Mountain group contribution } \\
\text { to the total number of glaciers in } \\
\text { South Tyrol }(\%)\end{array}$ \\
\hline $\begin{array}{l}17 \text { - ORTLES-CEVEDALE } \\
23 \text { - VENOSTE ORIENTALI }\end{array}$ & 54 & 34.38 & 40.6 & 25.5 \\
\hline (PALLA BIANCA - SIMILAUN) & 33 & 19.22 & 22.7 & 15.6 \\
\hline $\begin{array}{l}24 \text { - VENOSTE ORIENTALI-PASSIRIE } \\
\text { (TESSA) }\end{array}$ & 22 & 2.99 & 3.5 & 10.4 \\
\hline 25 - BREONIE OCCIDENTALI & 12 & 9.65 & 11.4 & 5.7 \\
\hline $\begin{array}{l}26 \text { - BREONIE ORIENTALI E AURINE } \\
\text { (GRAN PILASTRO) }\end{array}$ & 51 & 9.00 & 10.6 & 24.1 \\
\hline 27 - ALTI TAURI - TRE SIGNORI & 21 & 3.68 & 4.4 & 9.9 \\
\hline 28 - VEDRETTE RIES & 19 & 5.66 & 6.7 & 9.0 \\
\hline TOTAL & 212 & 84.58 & 100 & 100 \\
\hline
\end{tabular}

from the CGI Inventory (data covering the time window 19581959), suggests an overall reduction of the glacier extent of about $30 \%$ (from $526.88 \mathrm{~km}^{2}$ in the end of the Fifties to $368.10 \mathrm{~km}^{2}$ in the present time). Considering the glacier Regions, an area loss was reported ranging from the stronger reduction experienced by glaciers in Friuli, Piedmont and Veneto to the smaller decrease of Lombardy and Aosta Valley glaciers. The glacier number resulted increased and 68 new ice bodies were found: in fact, 835 glaciers were listed in the CGI Inventory (this latter reported 838 glaciers, but three of them were located in France and then not suitable to be inserted in a national record of data). Conversely, the new inventory described 903 ice bodies. The number increase of glaciers is mainly due to both fragmentation phenomena (which are particularly frequent during a glacier retreating phase) and identification of glaciers without any previous mention in the 
G.A. Diolaiuti et al.: La Houille Blanche 2019, 5-6, 159-175

Table 9. Surface area and number of glaciers in Veneto sorted according to the mountain groups where they are located.

\begin{tabular}{lcccr}
\hline Mountain group & $\begin{array}{c}\text { Number of } \\
\text { glaciers }\end{array}$ & $\begin{array}{c}\text { Cumulative area } \\
\text { value }\left(\mathrm{km}^{2}\right)\end{array}$ & $\begin{array}{c}\text { Mountain group } \\
\text { contribution to the } \\
\text { region area (\%) }\end{array}$ & $\begin{array}{c}\text { Mountain group contribution } \\
\text { to the total number of glaciers } \\
\text { in Veneto (\%) }\end{array}$ \\
\hline 29 - CRISTALLO & 3 & 0.44 & 13.7 & 7.9 \\
22 - PALE SAN MARTINO & 5 & 0.29 & 9.0 & 13.2 \\
21 - MARMOLADA & 2 & 0.15 & 4.7 & 5.3 \\
30 - CIVETTA & 5 & 0.24 & 7.5 & 13.2 \\
31 - PELMO & 1 & 0.27 & 8.4 & 2.6 \\
32 - TOFANE & 4 & 0.19 & 5.9 & 10.5 \\
33 - ANTELAO & 4 & 0.49 & 15.3 & 10.5 \\
33 - MARMAROLE & 5 & 0.35 & 10.9 & 13.2 \\
34 - SORAPIS & 5 & 0.56 & 7.2 & 13.2 \\
35 - CADINI-POPERA & 4 & 0.23 & 100 & 10.5 \\
TOTAL & 38 & 3.21 & 100
\end{tabular}

Table 10. Surface area and number of glaciers in Friuli-Venezia Giulia sorted according to the mountain groups.

\begin{tabular}{lcccc}
\hline \multicolumn{1}{c}{ Mountain group } & $\begin{array}{c}\text { Number of } \\
\text { glaciers }\end{array}$ & $\begin{array}{c}\text { Cumulative area } \\
\text { value }\left(\mathrm{km}^{2}\right)\end{array}$ & $\begin{array}{c}\text { Mountain group } \\
\text { contribution to the total } \\
\text { region area (\%) }\end{array}$ & $\begin{array}{c}\text { Mountain group contribution } \\
\text { to the total number of glaciers in } \\
\text { Friuli Venezia-Giulia (\%) }\end{array}$ \\
\hline 36-CANIN-MONTASIO & 7 & 0.19 & 100 & 100 \\
TOTAL & 7 & 0.19 & 100 & 100 \\
\hline
\end{tabular}

Table 11. Surface area and number of glaciers in Abruzzo.

\begin{tabular}{lcccc}
\hline \multicolumn{1}{c}{ Mountain group } & $\begin{array}{c}\text { Number of } \\
\text { glaciers }\end{array}$ & $\begin{array}{c}\text { Cumulative area } \\
\text { value }\left(\mathrm{km}^{2}\right)\end{array}$ & $\begin{array}{c}\text { Mountain group } \\
\text { contribution to the total } \\
\text { region area (\%) }\end{array}$ & $\begin{array}{c}\text { Mountain group contribution } \\
\text { to the total number of glaciers } \\
\text { in Abruzzo (\%) }\end{array}$ \\
\hline $37-$ GRAN SASSO D'ITALIA & 2 & 0.04 & 100 & 100 \\
TOTAL & 2 & 0.04 & 100 & 100 \\
\hline
\end{tabular}

past inventory (generally due to abundant supraglacial rock debris coverage which may have suggested in the past to consider the glacier extinct, whereas the high resolution source of data we analyzed permitted to detect evidence of glacier activity, to recognize the ice body and insert its data and features in the new inventory). A second comparison is also possible against the WGI dataset which between the half of the Seventies and the beginning of the Eighties listed 1381 Italian glaciers covering a total area of $608.56 \mathrm{~km}^{2}$. This comparison, even if rather difficult, suggests a loss of 478 glaciers and an area reduction of $240.46 \mathrm{~km}^{2}$ ( $40 \%$ of the total) $(39 \%$ in Smiraglia et al., 2015). The largest decrease is found in Friuli (73\%), Piedmont (57\%) and Trentino (56\%). Ranzi (2014) analyzed three ASTER images 2001-2003 (Sabbione in Piedmont, Pustertal in South Tyrol and Dolomites) and detected 56 glaciers from 0.01 to $2.69 \mathrm{~km}^{2}$; by comparing glacier extent with WGI dataset, an average area loss of $41 \%$ was recognized. Recently, a new database of the Italian glaciers has been produced by Salvatore et al. (2015) by using the 2006-2007 orthophotos freely available from the Geoportale Nazionale (http://www.pcn.minambiente.it/GN/). They evaluated a total glacier area of $387.4 \mathrm{~km}^{2}$ and a decrease compared to the CGI Inventory of ca. $140 \mathrm{~km}^{2}(-27 \%)$. The reduction from WGI is reported to be $120 \mathrm{~km}^{2}$ (approximately $-20 \%)$.

\section{Conclusion}

This study, thanks to the manual delineation of glaciers boundaries and the high-resolution sources, presents an updated picture of the Italian glaciers. In Italy, we found 903 ice bodies covering $368.10 \mathrm{~km}^{2}$ and corresponding to about $18 \%$ of the total glacierized area of the Alps (Paul, 2010; Paul et al., 2011). Almost all Italian glaciers are located in the Alps except two ice bodies situated on the Apennines. The widest Italian ice body is the Adamello ice cap, covering $16.30 \mathrm{~km}^{2}$ in Lombardy and Trentino. The Italian glaciation is 


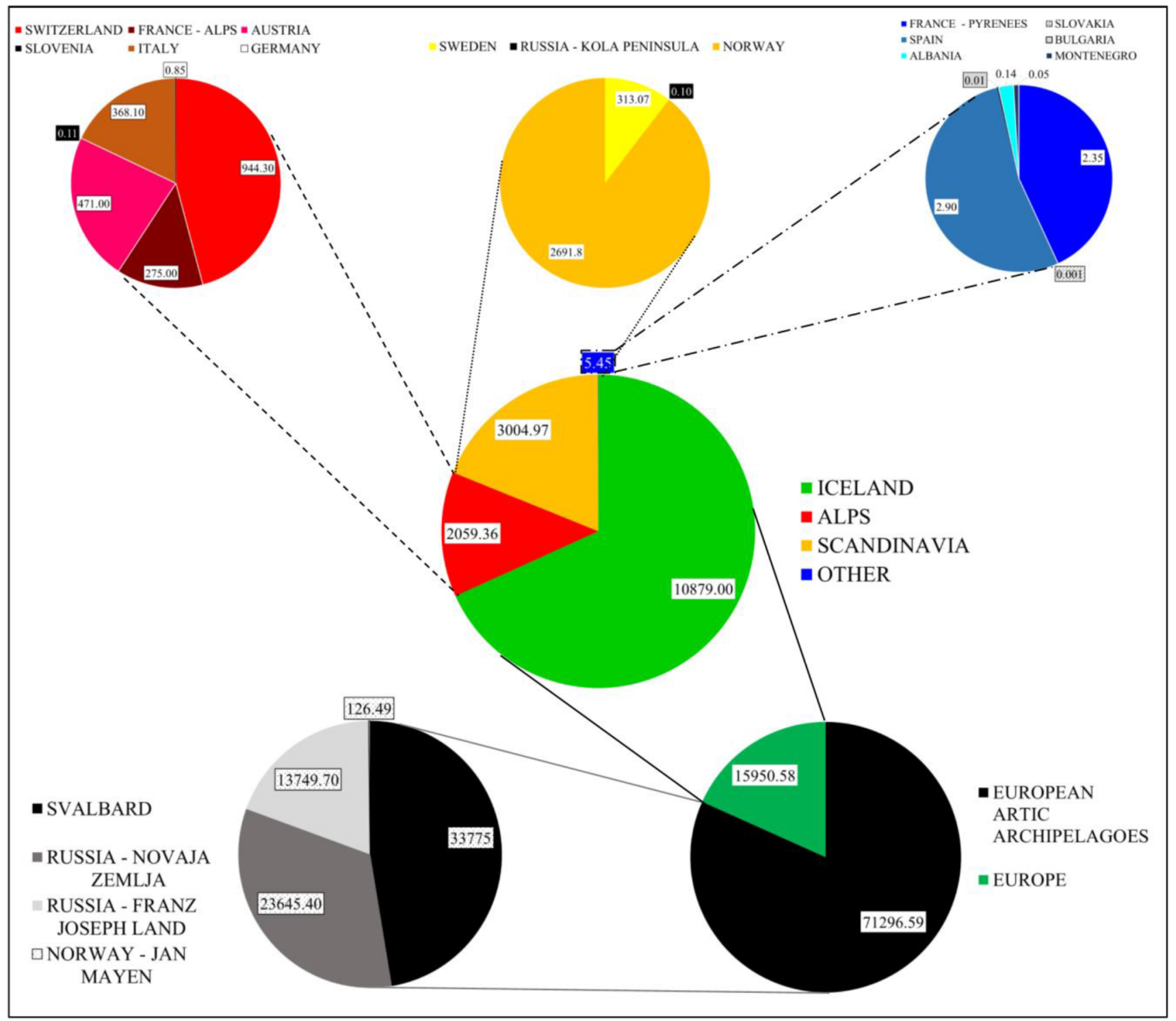

Fig. 7. Pie chart of the distribution of the European glaciers. The label indicates the glacier surface expressed in $\mathrm{km}^{2}$.

reported according to the Regional distribution, thus making the Aosta Valley the most glacierized one with $132.90 \mathrm{~km}^{2}$ corresponding to about $36 \%$ of the total value. The other areas featuring higher glaciation values are Lombardy $\left(87.67 \mathrm{~km}^{2}\right.$, the $24 \%$ of the total value) and South Tyrol $\left(84.58 \mathrm{~km}^{2}, 23 \%\right.$ of the total). The minima were found in Friuli-Venezia Giulia $\left(0.19 \mathrm{~km}^{2}, 0.05 \%\right)$ and in Abruzzo $\left(0.04 \mathrm{~km}^{2}, 0.01 \%\right)$. Regarding the glacier census, the highest number of glaciers was found in Lombardy (i.e. 230). On average, Italian glaciers cover an area of $0.41 \mathrm{~km}^{2}$ and $84 \%$ of ice bodies is smaller than $0.5 \mathrm{~km}^{2}$ covering only $21 \%$ of the total area. Moreover, only three glaciers are wider than $10 \mathrm{~km}^{2}$ (i.e. Adamello, Forni and Miage). The size classification is in accordance with the type classification: only 25 glaciers were labelled as "valley glacier" and the largest part was classified as "mountain glaciers" (i.e. 57.3\%) and "glacieret" (i.e. 40\%). Regarding the glacier aspect, the largest part of their area showed a prevalent North aspect (NW, N and NE); 61\% of the glacierized area and
$54 \%$ of the glaciers are exposed toward North, North-West and North East.

Comparing the New Italian Glacier Inventory to the whole European glaciation we found that Italian glaciers represent only $2 \%$ of the European glaciation (excluding the archipelagoes glaciers). The comparisons performed with previous inventories $(-30 \%$ respect to CGI Inventory and $-40 \%$ respect to the WGI Inventory) pointed out a strong glacier retreat in good agreement with the ones experienced by the other Alpine glacierized sectors. In this context, repeated remote sensing investigations are desirable to update glacier databases at a national scale and to evaluate how quickly this non-negligible water resource is being depleted.

Acknowlegments and thanks. Data and elaborations presented in the paper are mainly based on the results of the project "New Italian Glacier Inventory". This project was performed under the umbrella of an agreement among Università degli Studi di 
Milano, Sanpellegrino SPA - brand Levissima and EV-K2CNR Association and also taking advantage from the precious cooperation of the Comitato Glaciologico Italiano. We thank the governments of Lombardy Region, Piedmont Region, Valle d'Aosta Autonomous Region (RAVA, Fondazione Montagna Sicura), Veneto Region (ARPAV - Regional Department of Environmental Security, Centro Valanghe of Arabba), Autonomous Province of Trento and Autonomous Province of Bolzano - South Tyrol, for their kind help and the availability of high-resolution colour orthophotos. This work was also performed in the framework of the PRIN project 2010-2011 (2010AYKTAB_006).

\section{References}

Andreassen LM, Winsvold SH, Paul F, Hausberg JE. 2012. Inventory of Norwegian glaciers. In: Andreassen LM, Winsvold SH, eds. Oslo: NVE, $242 \mathrm{p}$.

Ajassa R, Biancotti A, Biasini A, et al. 1994. Catasto dei ghiacciai italiani: primo confronto tra i dati 1958 e 1989. Il Quaternario 7(1): 497-502.

Ajassa R, Biancotti A, Biasini A, Brancucci G, Carton A, Salvatore MC. 1997. Changes in the number and area of Italian Alpine glaciers between 1958 and 1989. Geogr Fis Din Quat 20: 293-297.

Belloni S, Catasta G, Smiraglia C. 1985. Problematiche e indicazioni per un nuovo catasto dei ghiacciai italiani sulla base del confronto fra il Catasto Italiano 1959-1962 e il World Glacier Inventory. Geogr Fis Din Quat 8: 166-181.

Beniston M, Farinotti D, Stoffel1 M, et al. 2018. The European mountain cryosphere: A review of its current state, trends, and future challenges. The Cryosphere 12: 759-794.

Bombarda R. 1995. I ghiacciai del gruppo Adamello-Presanella: variazioni dal 1865 e situazione attuale. Natura Alpina 46(2): 1-25.

Bombarda R. 1996. Il cuore bianco, Guida ai ghiacciai del Trentino. Milan (Italy): Arca Edizioni, 172 p.

Bombarda R, Parisi B. 1997. I ghiacciai (vedrette) delle Dolomiti di Brenta: centotrent'anni di frequentazione e di osservazioni. Geogr Fis Din Quat 20: 299-304.

Bonardi L, Rovelli E, Scotti R, Toffaletti A, Urso M, Villa F. 2012. I ghiacciai della Lombardia, evoluzione ed attualità. Milano: Hoepli ed., $328 \mathrm{p}$.

Brohan P, Kennedy JJ, Harris I, Tett SFB, Jones PD. 2006. Uncertainty estimates in regional and global observed temperature changes: A new dataset from 1850. J Geophys Res 111(D12106): $1-21$.

Brunetti M, Maugeri M, Nanni T. 2000. Variations of temperature and precipitation in Italy from 1866 to 1995 . Theor Appl Climatol 65: 165-174.

Carton A. 2013. Le Vedrette sentinelle del clima. In: de Battaglia F, Carton A, Pistoia U (a cura di), eds. Dolomiti di Brenta. CIERRE Ed., 394 p.

Carturan L, Filippi R, Seppi R, et al. 2013a. Area and volume loss of the glaciers in the Ortles-Cevedale group (Eastern Italian Alps): Controls and imbalance of the remaining glaciers. The Cryosphere 7: 1339-1359.

Carturan L, Baldassi AB, Bondesan A, et al. 2013b. Current behaviour and dynamics of the lowermost Italian glacier (Montasio Occidentale, Julian Alps). Geogr Ann Ser A 95: 79-96.

Casty C, Wanner H, Luterbacher J, Esper J, Böhm R. 2005. Temperature and precipitation variability in the European Alps since 1500. Int J Climatol 25: 1855-1880.
Citterio M, Diolaiuti G, Smiraglia C, et al. 2007. The fluctuations of Italian glaciers during the last century: A contribution to knowledge about Alpine glacier changes. Geogr Ann A 89(A3): 164-182.

Cogley JG, Hock R, Rasmussen LA, et al. 2011. Glossary of glacier mass balance and related terms. IHP-VII Technical Documents in Hydrology No. 86, IACS Contribution No. 2. Paris: UNESCO-IHP.

Colucci RR, Guglielmin M. 2015. Precipitation-temperature changes and evolution of a small glacier in the southeastern European Alps during the last 90 years. Int J Climatol 35(10): 2783-2797.

Colucci RR, Forte E, Boccali C, et al. 2015. Evaluation of internal structure, volume and mass of glacial bodies by integrated LiDAR and ground penetrating radar (GPR) surveys: The case study of Canin Eastern Glacieret (Julian Alps, Italy). Surv Geophys 36(2): 231-525.

Comitato Glaciologico Italiano-Consiglio Nazionale Delle Ricerche. 1959. Catasto dei Ghiacciai Italiani, Anno Geofisico Internazionale 1957-1958. Elenco generale e bibliografia dei ghiacciai italiani. Torino: Comitato Glaciologico Italiano eds., v. 1, $172 \mathrm{p}$.

Comitato Glaciologico Italiano-Consiglio Nazionale Delle Ricerche. 1961a. Catasto dei Ghiacciai Italiani, Anno Geofisico Internazionale 1957-1958. Ghiacciai del Piemonte. Torino: Comitato Glaciologico Italiano eds., v. 2, 324 p.

Comitato Glaciologico Italiano-Consiglio Nazionale Delle Ricerche. 1961b. Catasto dei Ghiacciai Italiani, Anno Geofisico Internazionale 1957-1958. Ghiacciai della Lombardia e dell'Ortles-Cevedale. Torino: Comitato Glaciologico Italiano eds., v. 3, $389 \mathrm{p}$.

Comitato Glaciologico Italiano-Consiglio Nazionale Delle Ricerche. 1962. Catasto dei Ghiacciai Italiani, Anno Geofisico Internazionale 1957-1958. Ghiacciai delle Tre Venezie (escluso Ortles-Cevedale) e dell'Appennino. Torino: Comitato Glaciologico Italiano eds., v. 4, 309 p.

Comitato Glaciologico Trentino. 1994. I ghiacciai del Parco Naturale Adamello-Brenta. Trento: Parco Adamello-Brenta, Nuova Stampa Rapida eds., 127 p.

Crepaz A, Cagnati A, De Luca G. 2013. Evoluzione dei ghiacciai delle Dolomiti negli ultimi cento anni. Neve e Valanghe 80: 20-25.

D'Agata C, Bocchiola D, Maragno D, Smiraglia C, Diolaiuti G. 2014. Glacier shrinkage driven by climate change in the Ortles-Cevedale group (Stelvio National Park, Lombardy, Italian Alps) during half a century (1954-2007). Theor Appl Climatol 116(1-2): 169-190.

D'Alessandro L, D'Orefice M, Pecci M, Smiraglia C. 2001. The strong reduction phase of the Calderone Glacier during the last two centuries: Reconstruction of the variation and of the possible scenarios with GIS technologies. In: Visconti G, Beniston M, Jannorelli E, Barba D, eds. Global change and protected areas. Dordrecht (the Netherlands): Kluwer, pp. 425-433.

Desio A. 1967. I ghiacciai dell'Ortles Cevedale. Vol. I, Testo. Torino: Comitato Glaciologico Italiano Eds.

Desio A. 1968. I ghiacciai dell'Ortles Cevedale. Vol. II, Tavole. Torino: Comitato Glaciologico Italiano Eds.

Diolaiuti G, Maragno D, D'Agata C, Smiraglia C, Bocchiola D. 2011. A contribution to the knowledge of the last fifty years of Alpine glacier history: The 1954-2003 area and geometry changes of Dosdè Piazzi glaciers (Lombardy-Alps, Italy). Prog Phys Geogr 35 (2): 161-182.

Diolaiuti G, Bocchiola D, D'Agata C, Smiraglia C. 2012a. Evidence of climate change impact upon glaciers' recession within the Italian alps: The case of Lombardy glaciers. Theor Appl Climatol 109(34): $429-445$. 
Diolaiuti G, Bocchiola D, Vagliasindi M, D'Agata C, Smiraglia C. 2012b. The 1975-2005 glacier changes in Aosta Valley (Italy) and the relations with climate evolution. Prog Phys Geog 36(6): 764-785.

D'Orefice M, Pecci M, Smiraglia C, Ventura R. 2000. Retreat of Mediterranean glaciers since the Little Ice Age: Case study of Ghiacciaio del Calderone, Central Apennines, Italy. Arct Antarct Alp Res 32(2): 197-201.

Fisher M, Huss M, Barboux C, Hoelzle M. 2014. The new Swiss Glacier Inventory SGI2010: Relevance of using High-resolution source data in areas dominated by very small glaciers. Arct Antarct Alp Res 46(4): 933-945.

Fiucci A, Gigante B, Rossi C, Smiraglia C, Veggetti O. 1997. The Calderone Glacier (Gran Sasso d'Italia): Determination of ice thickness and bedrock morphology by means of radio-echo sounding. Geogr Fis Din Quat 20: 305-308.

Gachev E, Gikov A, Zlatinova C, Blagoev B. 2009. Present state of Bulgarian glacierets. Landform Analysis 11: 16-24.

Gadek B, Grabiec M. 2008. Glacial ice and permafrost distribution in the Medena Kotlina (Slovak Tatras): Mapped with application of GPR and GST measurements. Stud Geomorphol CarpathoBalcanica 42: 5-22.

Gardent M, Rabatel A, Dedieu JP, Deline P. 2014. Multitemporal glacier inventory of the French Alps from the late 1960s to the late 2000s. Global Planet Change 120: 24-37.

González Trueba JJ, Martín Moreno R, Martínez De Pisón E, Serrano E. 2008. "Little Ice Age" glaciation and current glaciers in the Iberian Peninsula. Holocene 18: 551-568.

Hagg W, Mayer C, Mayr E, Heilig A. 2012. Climate and glacier fluctuations in the Bavarian Alps during the past 120 years. Erdkunde 66: 121-142.

Hughes PD. 2007. Recent behaviour of the Debeli Namet glacier, Durmitor, Montenegro. Earth Surf Proc Land 32: 1593-1602.

Hughes PD. 2009. Twenty-first century glaciers and climate in the Prokletije Mountains, Albania. Arct Antarct Alp Res 41(4): 455-459.

Isotta FA, Frei C, Veilguni V, et al. 2014. The climate of daily precipitation in the Alps: Development and analysis of a highresolution grid dataset from pan-Alpine rain-gauge data. Int $J$ Climatol 34(5): 1657-1675.

Kargel JS, Leonard GJ, Bishop MP, Kaab A, Raup B, eds. 2014. Global land ice measurements from space. Berlin (Germany): Springer-Praxis, 33 chapters, 876 p. ISBN: 978-3-540-79817-0.

Kirkbride M. 2011. Debris covered-glaciers. In: Singh VP, Singh P, Haritashya UK, eds. Encyclopedia of snow, ice and glaciers. Berlin (Germany): Springer, pp. 190-192.

Knoll C, Kerschner H. 2009. A glacier inventory for South Tyrol, Italy, based on airborne laser scanner data. J Glaciol 50: 46-52.

Lambrecht A, Kuhn M. 2007. Glacier changes in the Austrian Alps during the last three decades, derived from the new Austrian glacier inventory. Ann Glaciol 46: 177-184.

Lucchesi S, Bertotto S, Fioraso G, Chiarle M. 2014. Little Ice Age and contemporary glacier extent in the Western and SouthWestern Piedmont Alps (North-Western Italy). J Maps 10(3): 409-423.

Maragno D, Diolaiuti G, D'Agata C, et al. 2009. New evidence from Italy (Adamello Group, Lombardy) for analysing the ongoing decline of Alpine glaciers. Geogr Fis Din Quat 32: 31-39.

Marinelli O. 1910. I ghiacciai delle Alpi Venete. Mem Geogr G Dainelli 11: 1-289.

Mercalli L, Cat Berro D. 2005. Climi, acque e ghiacciai tra Gran Paradiso e Canavese. Bussoleno: Società Meteorologica Subalpina, $756 \mathrm{p}$.
Müller F, Caflish T, Müller G. 1977. Instructions for compilation and assemblage of data for a World Glacier Inventory Temporary Technical Secretariat (TTS) for the World Glacier Inventory. Zurich: ETH, 19 p.

Nigrelli G, Lucchesi S, Bertotto S, Fioraso G, Chiarle M. 2014. Climate variability and Alpine glaciers evolution in Northwestern Italy from the Little Ice Age to the 2010s. Theor Appl Climatol 122 (3): 595-608

Norbiato D, Borga M, Sangati M, Zanon F. 2007. Regional frequency analysis of extreme precipitation in the eastern Italian Alps and the August 29, 2003 flash flood. J Hydrol 345: 149-166.

Nuth C, Kohler J, König M, et al. 2013. Decadal changes from a multi-temporal glacier inventory of Svalbard. The Cryosphere 7: 1603-1621.

Parco Naturale Adamello Brenta, Comitato Glaciologico Trentino. 1994. I ghiacciai del Parco Naturale Adamello Brenta/Catasto. Trento: Comitato Glaciologico Trentino, pp. 96-120.

Paul F. 2010. Towards a global glacier inventory from satellite data. Geogr Helv 65(2): 103-112.

Paul F, Huggel C, Kääb A. 2004a. Combining satellite multispectral image data and a digital elevation model for mapping debriscovered glaciers. Remote Sens Environ 89: 510-518.

Paul F, Kääb A, Maisch M, Kellenberger T, Haeberli W. 2004b. Rapid disintegration of Alpine glaciers observed with satellite data. Geophys Res Lett 31(21): L21402.

Paul F, Kääb A, Haeberli W. 2007. Recent glacier changes in the Alps observed from satellite: Consequences for future monitoring strategies. Global Planet Change 56: 111-122.

Paul F, Barry RG, Cogley JG, et al. 2009. Recommendations for the compilation of glacier inventory data from digital sources. Ann Glaciol 50(53): 119-126.

Paul F, Frey H, Le Bris R. 2011. A new glacier inventory for the European Alps from Landsat TM scenes of 2003: Challenges and results. Ann Glaciol 52(59): 144-152.

Pecci M, De Sisti G, Marino A, Smiraglia C. 2001. New radar surveys in monitoring the evolution of the Calderone glacier (Central Apennines, Italy). Suppl Geogr Fis Dinam Quat V: 145-150.

Pecci M, D'Agata C, Smiraglia C. 2008. Ghiacciaio del Calderone (Apennines, Italy): The mass balance of a shrinking mediterranean glacier. Geogr Fis Din Quater 31: 55-62.

Pfeffer WT, Arendt AA, Bliss A, et al. 2014. The Randolph Glacier Inventory: A globally complete inventory of glaciers. J Glaciol 60 (221): 537-552.

Piccini P. 2007. Ghiacciai in Valsesia. Bussoleno: Società Meteorologica Subalpina, $134 \mathrm{p}$.

Porro C. 1925. Elenco dei Ghiacciai Italiani. Parma: Ufficio Idrografico del Po eds, $61 \mathrm{p}$.

Porro C, Labus P. 1927. Atlante dei Ghiacciai Italiani. Firenze: Istituto Geografico Militare eds.

Racoviteanu AE, Arnaud Y, Williams MW, Ordonez J. 2008. Decadal changes in glacier parameters in the Cordillera Blanca, Peru, derived from remote sensing. J Glaciol 54(186): 499-510.

Ranzi R. 2014. Italy. Glacier retreat: Glaciers in the Sabbione, Pustertal and Dolomites regions. In: Paul F, Arnaud Y, Ranzi R, Rott H, eds. European Alps. In: Kargel JS, Leonard GJ, Kaab A, Raup BH, eds. Global land ice measurements from space. Berlin (Germany): Springer, pp. 450-455.

Rau F, Mauz F, Vogt S, Khalsa SJS, Raup B. 2005. Illustrated GLIMS glacier classification manual: Glacier classification guidance for the GLIMS glacier inventory. Freiburg, Germany: Institut fur Physische Geographie, 36 p.

Renè P. 2001. Les glaciers des Pyrénées francaises. Boletín Glaciológico Aragonés 4: 31-68. 
Salvatore C, Zanoner T, Baroni C, et al. 2015. The State of Italian glaciers: A snapshot of the 2006-2007 hydrological period. Geogr Fis Dinam Quat 38(2): 175-198.

Secchieri F. 2012. I ghiacciai delle Dolomiti. Battaglia Terme: La Galiverna eds., 222 p.

Serandrei-Barbero R, Zanon G. 1993. The Italian Alps. In: Williams RS, Ferrigno JG, eds. Satellite image atlas of glaciers of the world-Europe, USGS Professional Paper 1386-E. Washington D. C.: USGS.

SGL-Servizio Glaciologico Lombardo. 1992. Ghiacciai in Lombardia. Bergamo: Bolis eds, 368 p.

Smiraglia C, Diolaiuti G. 2011. Epiglacial morphology. In: Singh VP, Singh P, Haritashya UK, eds. Encyclopedia of snow, ice and glaciers. Dordrecht (the Netherlands): Springer, pp. 262-268.

Smiraglia C, Diolaiuti G, eds. 2015. The new Italian glacier inventory. Bergamo: EV-K2-CNR Publ., 400 p.

Smiraglia C, Azzoni RS, D'Agata C, Maragno D, Fugazza D, Diolaiuti G. 2015. The evolution of the Italian glaciers from the previous data base to the New Italian Inventory. Preliminary considerations and results. Geogr Fis Dinam Quat 38(1): 79-87.

Triglav Čekada M, Zorn M, Colucci RR. 2014. Changes in the area of the Canin (Italy) and Triglav glaciers (Slovenia) since 1893 based on archive images and aerial laser scanning. Geod Vestn 58(2): 274-313.

Vögtle T, Schilling KJ. 1999. Digitizing Maps. In: Bähr HP, Vögtle T, eds. GIS for environmental monitoring. Stuttgart: Schweizerbart, pp. 201-216.

WGMS. 2012. Fluctuations of Glaciers 2005-2010. Volume X. In: Zemp M, Frey H, Gärtner-Roer I, Nussbaumer SU, Hoelzle M, Paul F, Haeberli W, eds. ICSU(WDS)/IUGG(IACS)/UNEP/UNESCO/ WMO. Zurich, Switzerland: World Glacier Monitoring Service, $336 \mathrm{p}$.

WGMS, NSIDC. 1989, updated 2012. World glacier inventory. Compiled and made available by the World Glacier Monitoring Service, Zurich, Switzerland, and the National Snow and Ice Data Center, Boulder CO, U.S.A. DOI: 10.7265/N5/NSIDC-WGI2012-02.

Zanon G. 1990. I Ghiacciai del Veneto. Treviso, Italia: Canova Eds, $80 \mathrm{p}$.

Zemp M, Haeberli W, Hoelzle M, Paulf F. 2006. Alpine glaciers to disappear within decades? Geophys Res Lett 33(13): L13504.

Zemp M, Frey H, Gärtner-Roer I, et al. 2015. Historically unprecedented global glacier decline in the early 21 st century. $J$ Glaciol 61(228): 745-762.

Cite this article as: Diolaiuti GA, Azzoni RS, D'Agata C, Maragno D, Fugazza D, Vagliasindi M, Mortara G, Perotti L, Bondesan A, Carton A, Pecci M, Dinale R, Trenti A, Casarotto C, Colucci RR, Cagnati A, Crepaz A, Smiraglia C. 2019. Present extent, features and regional distribution of Italian glaciers. La Houille Blanche 5-6: 159-175. 